\title{
Assessment of emergency contraceptives utilization and associated factors among female college students at Debre Tabor town
}

Tadesse Wuletaw Demissie ${ }^{1 *}$, Araya Mesfin Nigatu² and Getnet Mihretie Beyene $e^{2,3}$

\begin{abstract}
Background: Unwanted pregnancy is a significant public health problem worldwide. In higher education, students are exposed to the risk of unintended pregnancy, abortion, and its related negative consequences.

Objective: The objective of this study was to assess the magnitude of emergency contraceptives and factors associated with its utilization among college female students at Debre Tabor Town, Northwest Ethiopia.

Methods: A cross-sectional, institutional-based study was conducted from June to October 2017. A multi-stage stratified sampling technique was applied to select the study participants. Data were cleaned, coded, and entered into Epi info 7 and exported to SPSS version 20 for analysis. Bivariable and multivariable logistic regression was used to identify the association between the use of emergency contraception and the predictor variables. The $P$-value less than 0.05 at $95 \% \mathrm{Cl}$ was taken as statistical significance.

Results: A total of 821 respondents participated with a response rate of $97.6 \%$. The finding showed that $33.3 \%$ of them have used emergency contraceptives following unprotected sex. Female students' knowledge about emergency contraceptive [AOR: $2.3 ; 95 \% \mathrm{Cl} 1.20,4.25$ ], age with 20-24 years category [AOR: 2.3; 95\% Cl 1.21, 4.49] and married [AOR: $2.8 ; 95 \% \mathrm{Cl} 1.22,6.21$ ] and divorced [AOR: 4.9; $95 \% \mathrm{Cl} 1.12,21.08$ ] students were found to be significant predictors of EC utilization.

Conclusions: This study revealed that the level of emergency contraceptive utilization was low. Students' level of knowledge about an emergency contraceptive, age at present, and marital status were found to be the major predictor for emergency contraceptive utilization. Therefore, responsible bodies should develop strategies that enhance the knowledge level of students at the college level on the effective utilization of emergency contraceptive methods.
\end{abstract}

Keywords: EC utilization, Ethiopia

\footnotetext{
* Correspondence: twuletaw@yahoo.com

'Department of Nursing, Debre Tabor Health Science College, Debra Tabor, Ethiopia

Full list of author information is available at the end of the article
}

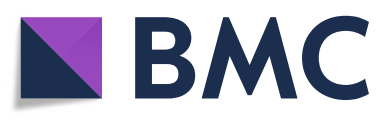

(c) The Author(s). 2020 Open Access This article is licensed under a Creative Commons Attribution 4.0 International License, which permits use, sharing, adaptation, distribution and reproduction in any medium or format, as long as you give appropriate credit to the original author(s) and the source, provide a link to the Creative Commons licence, and indicate if changes were made. The images or other third party material in this article are included in the article's Creative Commons licence, unless indicated otherwise in a credit line to the material. If material is not included in the article's Creative Commons licence and your intended use is not permitted by statutory regulation or exceeds the permitted use, you will need to obtain permission directly from the copyright holder. To view a copy of this licence, visit http://creativecommons.org/licenses/by/4.0/. The Creative Commons Public Domain Dedication waiver (http://creativecommons.org/publicdomain/zero/1.0/) applies to the data made available in this article, unless otherwise stated in a credit line to the data. 


\section{Plain English summary}

Unwanted pregnancy is a significant public health problem worldwide, particularly in developing countries. In higher education, students are exposed to the risk of unintended pregnancy, abortion, and its related negative consequences.

Students were asked to use an interview-based questionnaire for their exposure and utilization of emergency contraceptives and their associated factors.

A total of 821 respondents participated with a response rate of $97.6 \%$. The finding showed that $33.3 \%$ of them have used emergency contraceptives following unprotected sex. Female students' knowledge about an emergency contraceptive, age with 20-24 years category, and married and divorced students were found to be significant predictors of EC utilization.

\section{Article summary \\ Strength}

College students were asked using an interview-based questionnaire for their exposure and utilization of emergency contraceptives and their associated factors.

Responsible bodies particularly college higher officials', policymakers, and health professionals were informed to develop strategies that enhance the knowledge level of students on the effective utilization of emergency contraceptive methods; this could enhance female student's knowledge and use of emergency contraceptives.

\section{Limitation}

As the study was a cross-sectional egg -chicken dilemma may happen and as the reproductive issues are sensitive, students may feel shame to explain their emergency contraceptive utilization and other reproductive issues fully.

\section{Background}

Emergency contraception also called: "post-coital contraception", or "second chance" is a type of modern and traditional contraception that is used after unprotected sexual intercourse, following sexual abuse, misuse of regular contraception, or non-use of contraception [1].

Every year, more than 120 million couples have an unmet need for contraception and 80 million women have unintended pregnancies from which 45 million of them end up with abortion; this mainly results from unsafe sex which is the second most important risk factor for disability and death in the world's poorest communities [2].

As it is difficult to determine the infertile time of the cycle with certainty; emergency contraceptive methods should be provided for any woman concerned about her risk of pregnancy regardless of the cycle and day of exposure; there are two types of emergency contraceptive methods: the emergency contraceptive pill (the "morning after" pill) and the intrauterine device (IUD) [3]. Hormonal emergency contraceptive pills are taken within $72 \mathrm{~h}$ of unprotected sexual intercourse and then $12 \mathrm{~h}$ late. Whereas progesterone-only pills one pill should be taken as the first dose as soon as convenient, but not later than 3 days (72 h) after unprotected intercourse to be followed by another one pill $12 \mathrm{~h}$ later;Levonelle has to be taken within $72 \mathrm{~h}(3$ days) of un protected sex to prevent pregnancy and ellaOne(containing ulipristal acetate) has to be taken within 120 $\mathrm{h}$ (5 days) of sex to prevent pregnancy and the copper bearing IUCD be inserted within 5 days of un protected sex when used as an emergency contraceptive method; it is more effective than the contraceptive pill in preventing pregnancy; less than $1 \%$ of women get pregnant. The sooner the methods are used, the more effective after the act of an intended intercourse [4].

Even though, users report some side effects of emergency contraceptives like irregular bleeding, headache, nausea, weight, and mood changes [1]. If used correctly, all types of EC pills can decrease the risk of unintended pregnancy by $75 \%$ which in turn helps to reduce unplanned pregnancy and unsafe abortion [5].

A systematic review of causes of maternal mortality estimated that abortion accounted for $49 \%$ of deaths and millions more have complications; half of the deaths occur in Africa where one in four unsafe abortions is done with teenagers [6].

Despite the technological advancements in modern contraceptive methods, unintended pregnancy is still a big health problem but can be minimized by the proper utilization of emergency contraceptives. However different findings in middle and low-income countries revealed that EC utilization proportion was $29 \%$ in China, 21.2\% in South Africa, 13.3\% in Nigeria, 39.9\% in Ghana, and $2.7 \%$ in Ethiopia [7-11].

Emergency contraceptives utilization can play an important role in reducing un planned pregnancies and thereby reducing the risk of un planned pregnancy, its associated health risks, social problem and furthermore prevents economic problems, but there were limited studies in the study area. Therefore, the objective of this study was to assess the magnitude of emergency contraceptive utilization and its associated factors among female college students at Debre Tabor Town.

\section{Methods}

\section{Study design, setting, and participants}

An institutional-based cross-sectional study was conducted to assess the prevalence of emergency contraceptive utilization and associated factors among female college students learning at Debre Tabor Town, Amhara Regional State, and Northwest Ethiopia. The study was conducted among three governmental and two private colleges (namely; Debre Tabor Health Science College, Debre Tabor Poly Technique College, Begemdir Teachers College, 
Fekede Egzi College, and Guna Tabor Business and Health Science College) found in Debre Tabor Town from June to October 2017. There were a total of 800 female students attending their education. The town is located $667 \mathrm{~km}$ from Addis Ababa (the capital city of Ethiopia) in the Northwest direction of the country and $97 \mathrm{~km}$ away from Bahir Dar city (the capital city of the region) toward the east direction.

It has also 4 kebeles (the smallest local administrative units), three public health centers, one general hospital, three medium private clinics, one primary clinic, three drug stores, and two pharmacies with an area of 3187.07 ha. It has 81, 644 estimated total population, and from which 40,985 were women. Of the 40,985 females, 19,252 were within the reproductive age at the time of the study. The estimated annual delivery number within this period was 2751 births [12].

\section{Sample size and sampling techniques}

The sample size was determined using a single population proportion formula with the assumption of a $95 \%$ confidence interval and a margin of error of $5 \%$. From those who had sexual experience, the proportion of students who practiced emergency contraceptive methods was assumed to be 46.3\%(p) taken from the study conducted in southwest Ethiopia Mizan Tapi university brought larger sample size after considering others to have the required sample size [13]. Then, by adding a non-response rate of $10 \%$ and multiplying by a design effect of 2 , a sample of 840 was determined.

A two-stage sampling technique was used; in the first case departments were selected using the lottery method and then, the sample size was allocated to each department proportional to the number of female students in each department. Finally, participant students were selected from each department proportional to their year of study using a simple random sampling technique.

\section{Data collection procedures}

Data were collected using a self-administered Amharic version and a pretested questionnaire facilitated by two diploma nurses and one BSc nurse supervisor. It includes variables like socio-demographic characteristics, sexual and reproductive health history, knowledge, attitude, practice about EC and determinants of emergency contraceptive methods were asked.

\section{Data processing and analysis}

Data were entered, edited, and cleaned using Epi-info version 7 and exported to SPSS version 20 for further statistical analysis. The descriptive analysis such as proportions, percentages, frequency distribution, and measure of central tendency was carried out.

Next to this, the bivariate analysis was done to identify whether there was an association between the dependent and independent variables to select the candidate variable for the multivariable analysis. Accordingly, variables found to have an association with the dependent variable less than $0.2 p$-values were entered into multivariable binary logistic regression using the enter method for controlling the possible effects of confounders. Finally, the variables which had a significant association with p-value $<0.05$ were identified as significant variables based on the odds ratio (OR), with 95\% CI. The goodness of fit test was also checked.

\section{Operational definitions of terms Emergency contraceptive utilization}

Refers to methods that a woman can use to prevent pregnancy after unprotected sexual intercourse, method failure, or incorrect use.

\section{Data quality control measures}

The quality of data was assured by giving pre-test, training for data collectors, and supervisor on the objective of the study and making frequent supervision. The completeness of the questionnaire was checked every other day by the supervisors and principal investigators.

\section{Ethical considerations}

Ethical clearance was obtained from the Amhara Public Health Institution. Informed consent was also obtained from each study participant. Individual participant records were coded on each respective questionnaire and accessed only by the research team members to keep confidentiality.

\section{Results}

Socio-demographic characteristics of students

In this study, a total of 821 female college students participated in the study yielding a response rate of $97.6 \%$. The mean age of the respondents was 19.9 ( $\mathrm{SD} \pm 2.28$ ) years. The youngest being 15 and the oldest 35 years old. More than one third $(47.5 \%)$ of the respondents were between the age of 15-19 years. Above three fourth of (97\%), the respondents were Orthodox Christianity by religion. Concerning marital status, $678(83.7 \%)$ of the respondents were single (Table 1).

\section{Reproductive health characteristics}

The mean age at first sexual intercourse and first pregnancies were 18.8 $(\mathrm{SD} \pm 2.24)$ years and $19.9(\mathrm{SD} \pm 2.6)$ years respectively. Eighty-nine (33.8\%) of sexually active female students had had a pregnancy and 50(56.2\%) of them were below the age of 20 years. Sixty-seven (75.3\%) of pregnant respondents reported that their pregnancy was unplanned. Among those who reported unplanned pregnancy, $30(44.8 \%)$ failed to prevent pregnancy because of forgetting to take contraceptive methods namely oral contraceptives, and 9(13.4\%) having infrequent sex. Similarly, those of untended pregnancies, 55(82.1\%) of them end up with induced abortion mainly from governmental health facilities $33(60 \%)$. The major reasons for them to terminate 
Table 1 Socio-demographic characteristics of female college students Debre Tabor Town northwest Ethiopia, October 2017 $(n=821)$

\begin{tabular}{|c|c|c|}
\hline Variables & Frequency & Percent \\
\hline \multicolumn{3}{|l|}{ Age (in years) } \\
\hline $15-19$ & 3390 & 47.5 \\
\hline $20-24$ & 386 & 47.0 \\
\hline$>=25$ & 45 & 5.5 \\
\hline Mean \pm SD & $19.9 \pm 2.3$ & \\
\hline \multicolumn{3}{|l|}{ Marital status } \\
\hline Single & 678 & 83.7 \\
\hline Married & 98 & 11.9 \\
\hline Widowed & 5 & 0.6 \\
\hline Divorced & 27 & 3.3 \\
\hline Separated & 4 & 0.5 \\
\hline \multicolumn{3}{|l|}{ Religion } \\
\hline Orthodox & 796 & 97.0 \\
\hline Muslim & 20 & 2.4 \\
\hline Catholic & 4 & 0.5 \\
\hline Protestant & 1 & 0.1 \\
\hline \multicolumn{3}{|l|}{ Year of Study } \\
\hline 1st year & 562 & 68.5 \\
\hline 2nd year & 149 & 18.1 \\
\hline 3 rd year and above & 110 & 13.4 \\
\hline \multicolumn{3}{|l|}{ Field of study } \\
\hline Health Science & 302 & 36.8 \\
\hline Non-health Science & 519 & 63.2 \\
\hline \multicolumn{3}{|l|}{ Program } \\
\hline Regular & 678 & 82.6 \\
\hline Extension & 143 & 17.4 \\
\hline
\end{tabular}

their pregnancy were fear of discontinuing from school (50.9\%) followed by fear of parents (36.4\%) (Table 2).

Among the total participants, 456(55.5\%) of them said that they heard information about emergency contraceptives. From these, 228 (50\%) of them mentioned friends as their first source of information followed by mass media 105(23.04\%) (Table 2).

\section{Knowledge of emergency contraceptive utilization}

Among college female students who have heard about EC 456(55.5\%), only 254 (55.7\%) correctly identified the time of utilization of the method, 246(53.9\%) knew the recommended doses, and 169 (37.1\%) recognize the recommended time interval between the doses. The index knowledge summary about EC also showed that 207(45.4\%) of the respondents had good knowledge of EC (Table 3). Among 263 respondents who had a history
Table 2 Pregnancy and related characteristics among sexually active female college students Debre Tabor Town northwest Ethiopia, October 2017

\begin{tabular}{lll}
\hline Variables & Frequency & Percent \\
\hline Ever had sex $(\mathbf{n}=\mathbf{8 2 1})$ & & \\
yes & 263 & 32.0 \\
No & 558 & 68.0
\end{tabular}

Age at first sex $(n=263)$

$$
15-19
$$

$20-24$

$>=25$

Mean $( \pm$ SD)

Ever been pregnant $(n=263)$

$$
\text { Yes }
$$

No

Ever heard about EC $(n=821)$

$\begin{array}{lll}\text { Yes } & 456 & 55.5 \\ \text { No } & 365 & 44.5\end{array}$

What is your source of information

From friends 228

From health institutions

From mass media

From boyfriends

From parents

From college teachers

Age at first pregnancy $(n=89)$

15-19

20-24

$>=25$

Unintended pregnancy $(n=89)$

Yes

No

Induced abortion $(n=67)$

No

Place of abortion $(n=55)$

Untrained abortionist 5

Private clinic

Government health institution

Self-infliction

Reason for induced abortion $(n=55)$

$\begin{array}{lll}\text { Fear of discontinuing school } & 28 & 50.9 \\ \text { Fear of parents } & 20 & 36.4 \\ \text { Economic problem } & 11 & 20.0 \\ \text { Since unintended } & 10 & 18.2 \\ \text { Stigma } & 7 & 12.7\end{array}$


Table 3 knowledge about emergency contraceptive utilization among female college students in Debre Tabor Town northwest Ethiopia, October $2017(n=456)$

\begin{tabular}{l} 
Variables \\
\hline Methods reported as EC \\
Oral contraceptive pills \\
IUCD \\
Injectable \\
Condoms \\
Norplant \\
Withdrawal \\
Calendar/rhythm \\
All mentioned above \\
I don't know
\end{tabular}

Mechanism of action of pills as ECs

Prevent ovulation

Prevent fertilization

Prevent implantation

Induced abortion

All mentioned above

I don't know

Can Ec cause early abortion?

Yes

No

When taken early, can EC prevent STI?

Yes

No

Where EC can be obtained?

Pharmacy

Governmental health institution

Private clinics

All mentioned above

I don't know

Recommended time to take EC pills?

At any time

Within $72 \mathrm{~h}$

Within 5 days after sex

I don't know

The recommended dose of pills \& IUCD

respectively?
One dose
Two and above dose
I don't remember
I don't know

Recommended between doses of pills

Frequency Percent

Table 3 knowledge about emergency contraceptive utilization among female college students in Debre Tabor Town northwest Ethiopia, October 2017 ( $n=456)$ (Continued)

\begin{tabular}{|c|c|c|}
\hline Variables & Frequency & Percent \\
\hline $48 \mathrm{~h}$ apart & 89 & 19.5 \\
\hline $72 \mathrm{~h}$ apart & 171 & 37.5 \\
\hline \multicolumn{3}{|l|}{ I don't know } \\
\hline \multicolumn{3}{|l|}{ Recommended time for IUCD as EC } \\
\hline Within $24 \mathrm{~h}$ after sex & 54 & 11.8 \\
\hline Within $48 \mathrm{~h}$ after sex & 11 & 2.4 \\
\hline Within $72 \mathrm{~h}$ after sex & 39 & 8.6 \\
\hline Within 5 days after sex & 65 & 14.3 \\
\hline I don't know & 287 & 62.9 \\
\hline \multicolumn{3}{|l|}{ Effectiveness of EC pills } \\
\hline Very effective (99\%) & 145 & 31.8 \\
\hline Effective (75\%) & 41 & 9.0 \\
\hline Moderate (50\%) & 18 & 3.9 \\
\hline Less effective (30\%) & 20 & 4.4 \\
\hline I don't know & 232 & 50.9 \\
\hline \multicolumn{3}{|l|}{ Situation(s) that EC should be taken } \\
\hline When forced to have sex & 52 & 11.4 \\
\hline If condom raptured during sex & 27 & 5.9 \\
\hline When there are missed pills & 11 & 2.4 \\
\hline When there is sex without a contraceptive & 30 & 6.6 \\
\hline All mentioned above & 185 & 40.6 \\
\hline I don't know & 151 & 33.1 \\
\hline \multicolumn{3}{|l|}{ Knowledge of EC (summary index) } \\
\hline Good knowledge & 207 & 45.4 \\
\hline Poor knowledge & 249 & 54.6 \\
\hline
\end{tabular}

of sexual intercourse, $74(28.1 \%)$ of them used EC as contraception (Fig. 1).

\section{Attitude}

Three hundred sixty-four (44.3\%) of the respondents had a good attitude towards EC. Four hundred ninetyone $(59.8 \%)$ of the respondents replayed that EC will not cause loss of confidence between regular partners; so that 276(33.6\%) of the respondents strongly agreed that EC is useful for all at risk females. On the other hand, $230(28 \%)$ of the respondents agreed that will increase the risk of STI including HIV/AIDS (Table 4).

\section{Practice}

Among students who had ever been sexually active $28.1 \%$ of them used EC and from respondents who had unprotected sexual acts, 33.3\% of them used EC. Oral contraceptive pills were the most common method used followed by condoms accounting for 70.3 and $18.9 \%$ respectively. However, only 48.6 and $16.2 \%$ of them correctly identified the 


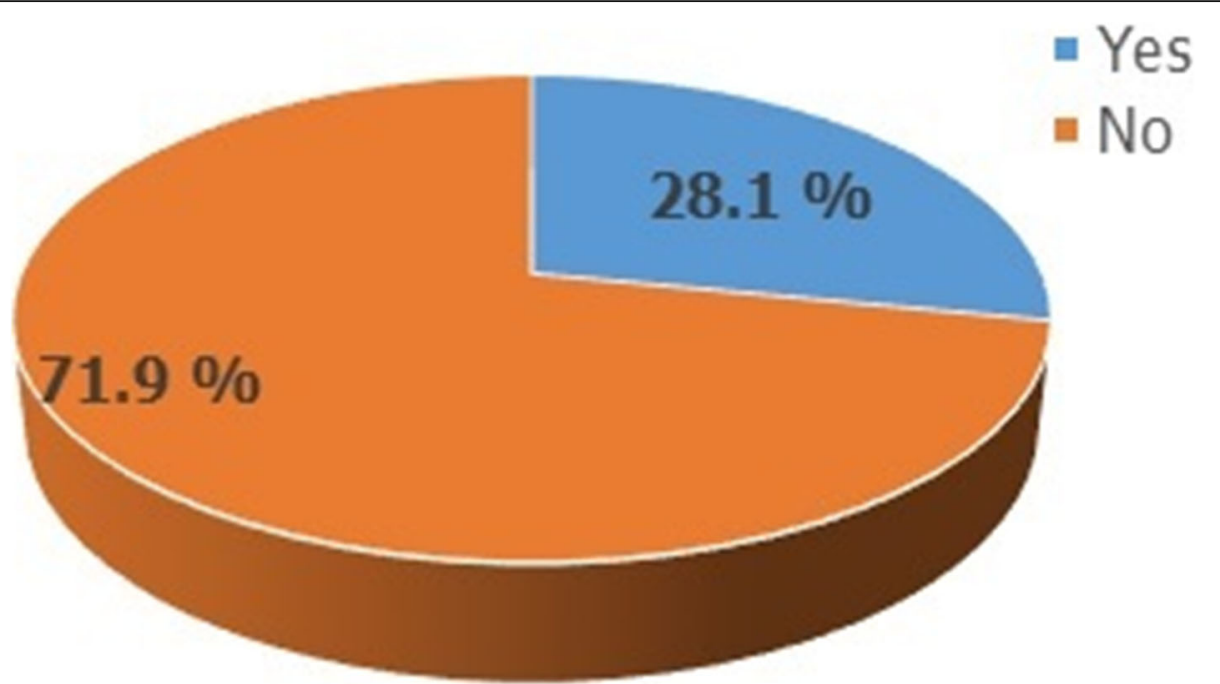

Fig. 1 Prevalence of EC users among college female students who had a history of sexual intercourse, Debre Tabor Town, Northwest Ethiopia October 2017

recommended time limit (that means within $72 \mathrm{~h}$. for pills and within $120 \mathrm{~h}$ for IUCD) respectively (Table 5). Twentythree $(62.2 \%)$ of the respondents were advised to use emergency contraceptive methods after unprotected sex by their female friends or peers (Fig. 2).

\section{Determinants of emergency contraceptive utilization}

The multivariable logistics regression analysis showed that college female students whose age category between
20 and 24 years $(\mathrm{AOR}=2.3,95 \% \mathrm{CI}: 1.21,4.49)$ were two times more likely to use EC as a contraception method. Married students (AOR $=2.8,95 \% \mathrm{CI}: 1.22,6.21)$ and divorced once $(\mathrm{AOR}=4.9,95 \% \mathrm{CI}: 1.12,21.08)$ were two and five times more likely to use EC as compared to unmarried students respectively. On the other hand, students who had good knowledge ( $\mathrm{AOR}=2.3,95 \% \mathrm{CI}$ : $1.20,4.25)$ were two times more likely to use EC as a contraception option (Table 6).

Table 4 Attitude on emergency contraceptive utilization among female college students in Debre Tabor Town northwest Ethiopia, October $2017(n=821)$

\begin{tabular}{|c|c|c|c|c|}
\hline \multirow[t]{2}{*}{ Variables } & \multicolumn{4}{|l|}{ Response } \\
\hline & Strongly disagree (\%) & Disagree (\%) & Agree (\%) & Strongly agree (\%) \\
\hline EC causes loose of confidence between regular partners & 189(20.6) & $491(59.8)$ & 148(18.0) & 13(1.6) \\
\hline EC is good for all females who are at risk & 210(25.6) & 142(17.3) & $193(23.5$ & 276(33.6) \\
\hline EC increases the risk of STI including HIV/AIDS & 183(22.3) & 191(23.3) & $230(28.0)$ & $217(26.4)$ \\
\hline EC is good after unsafe sexual intercourse & 192(23.4) & 152(18.5) & 234(28.5) & 243(29.6) \\
\hline EC is sign full contraceptive method & $172(21.0)$ & $272(33.1)$ & 212(25.8) & 165(20.1) \\
\hline EC may cause infertility & $47(5.7)$ & 188(22.9) & $250(30.5)$ & $336(40.9)$ \\
\hline If I had unintended sexual intercourse I would use EC & $41(5.0)$ & $80(9.7)$ & $237(28.9)$ & $463(56.4)$ \\
\hline $\begin{array}{l}\text { I would advise using EC for close friends if they had } \\
\text { unintended sexual intercourse }\end{array}$ & $70(8.5)$ & 108(13.2) & $313(38.1)$ & $330(40.2)$ \\
\hline EC promotes promiscuity & $148(18)$ & 298(36.3) & 196(23.9) & 179(21.8) \\
\hline $\mathrm{EC}$ is one way of abortion & 143(17.4) & 173(21.1) & $313(38.1)$ & 192(23.4) \\
\hline EC affect the regular contraceptive method & 101(12.3) & 279(34.0) & 2264(32.2) & 17(21.6) \\
\hline Unplanned sexual intercourse is a problem for all young females & 229(27.9) & $390(47.2)$ & $99(12.1)$ & 103(12.5) \\
\hline EC can be used for a long time & $145(17.7)$ & 198(24.1) & $300(36.5)$ & $178(21.7)$ \\
\hline \multicolumn{5}{|l|}{ Attitude (summary index) } \\
\hline Good Attitude & $364(44.3 \%)$ & & & \\
\hline Poor Attitude & 457 (55.7\%) & & & \\
\hline
\end{tabular}


Table 5 Emergency contraceptive practice among female college students, Debre Tabor Town, northwest Ethiopia, October 2017

\begin{tabular}{|c|c|c|}
\hline Variables & Frequency & Percent \\
\hline \multicolumn{3}{|l|}{$\begin{array}{l}\text { Ever used EC among those } \\
\text { who had sex }(n=263)\end{array}$} \\
\hline yes & 74 & 28.1 \\
\hline No & 189 & 71.9 \\
\hline \multicolumn{3}{|l|}{$\begin{array}{l}\text { Ever used EC among unprotected } \\
\text { sex }(n=111)\end{array}$} \\
\hline Yes & 37 & 33.3 \\
\hline No & 74 & 66.7 \\
\hline \multicolumn{3}{|l|}{ Methods used as EC $(n=37)$} \\
\hline OC pills & 26 & 70.3 \\
\hline IUCD & 1 & 2.7 \\
\hline Condom & 7 & 18.9 \\
\hline Withdrawal & 2 & 5.4 \\
\hline Calendar & 1 & 2.7 \\
\hline \multicolumn{3}{|l|}{ Place obtained $(n=37)$} \\
\hline Pharmacy & 11 & 29.7 \\
\hline Government health institutions & 3 & 8.1 \\
\hline Private clinics & 23 & 62.2 \\
\hline \multicolumn{3}{|l|}{ How many times used $(n=37)$} \\
\hline One dose & 6 & 16.2 \\
\hline Two and above & 18 & 48.6 \\
\hline I don't remember & 1 & 2.7 \\
\hline As necessary & 12 & 32.4 \\
\hline \multicolumn{3}{|l|}{ Time EC was used $(n=55)$} \\
\hline Within $72 \mathrm{~h}$ for pills & 14 & 37.8 \\
\hline Within $120 \mathrm{~h}$ for IUCD & 12 & 32.4 \\
\hline I used as I want & 10 & 27.0 \\
\hline I don't remember & 1 & 2.7 \\
\hline
\end{tabular}

\section{Discussion}

This study result showed that the utilization of EC was low. Knowledge of female students, age at present, and the marital status of the students were the major predictors of EC utilization.

In this study, we found that 33.3\% (95\% CI: 25.2, 42.3\%) of those who had unprotected sexual act used EC, which is similar to the report of the studies done at Adama University (Ethiopia) 26.7\% [14], Ghana 39.9\% [10] and China $29 \%$ [11], but was lower than studies done in Ethiopian universities like Mizan Tepi 46.3\% [13] and Adds Ababa $75 \%$ [15]. The difference might be due to low awareness, accessibility of EC methods, being in campus dormitory for those university students whereas in the private dormitory for college students; there is gender base and sexual health education in the colleges and universities by using gender clubs and clinics in the universities,but there may be difference in performance among the organizations. However, our study was higher than the study done in Ethiopia like Adama University 4.7\% [16], Hawasa 10.8\% [17], Jima 6.8\% [18] and abroad Nigeria (10 \&13.3\%) [8, 19] and South Africa 21.2\% [7]. The possible explanation for this might be a difference in socio-demographic and cultural background characteristics of the respondents and time-lapse.

A statistically significant association was obtained between the age of respondents and their EC utilization. Respondents whose age category is $20-24$ years $(\mathrm{AOR}=$ 2.3, 95\% CI: $1.21,4.49)$ were two times more likely to use EC as contraception compared to those within the age range of $15-19$ years old. The finding is similar to studies done in Ethiopia [13, 14, 16] and South Africa [7]. The probable reason for this could be younger students might have less information about the proper use of EC due to the fact that they were newly enrolled in the college and might not have received information in their prior schooling.

Another statistically significant association was also obtained between marital status and emergency contraceptive utilization of students. Respondents who were ever married $(\mathrm{AOR}=2.8,95 \% \mathrm{CI}: 1.22,1.21)$ and divorced $(\mathrm{AOR}=4.9,95 \% \mathrm{CI}: 1.12,21.08)$ were three and five times more likely to use emergency contraceptive respectively as compared to single ones. The finding is similar to studies done at Adama University (Ethiopia) $[14,16]$. The possible justification for this might be access to current information; married students might get current information on EC from their partners. Besides, the effect of marital status and increment in age on EC utilization could also be linked to issues like minimizing the fear of being seen by others.

Finally, another significant association was also found between respondents having good knowledge of EC and EC utilization. Respondents who had good knowledge $(\mathrm{AOR}=2.3,95 \% \mathrm{CI}: 1.20,4.25)$ were two times more likely to use emergency contraceptives as compared to those having poor knowledge. This finding was consistent with studies conducted in Ethiopian Universities like Mizan Tepi [13], Arba Minch [20], and Adama [14]. The possible reason for this might be a good knowledge. Students who had good knowledge would help them to identify where, when, and how to use EC in preventing unintended pregnancy and abortion that could result from unprotected sex.

Although the finding of this study may not be generalized to students who are out of colleges, it has demonstrated the sexual and reproductive health problems faced by students in colleges found at Debre Tabor. Since an anonymous self-administered questionnaire was used, the possibility of social desirability bias cannot be eliminated as the study touches sensitive issues. 


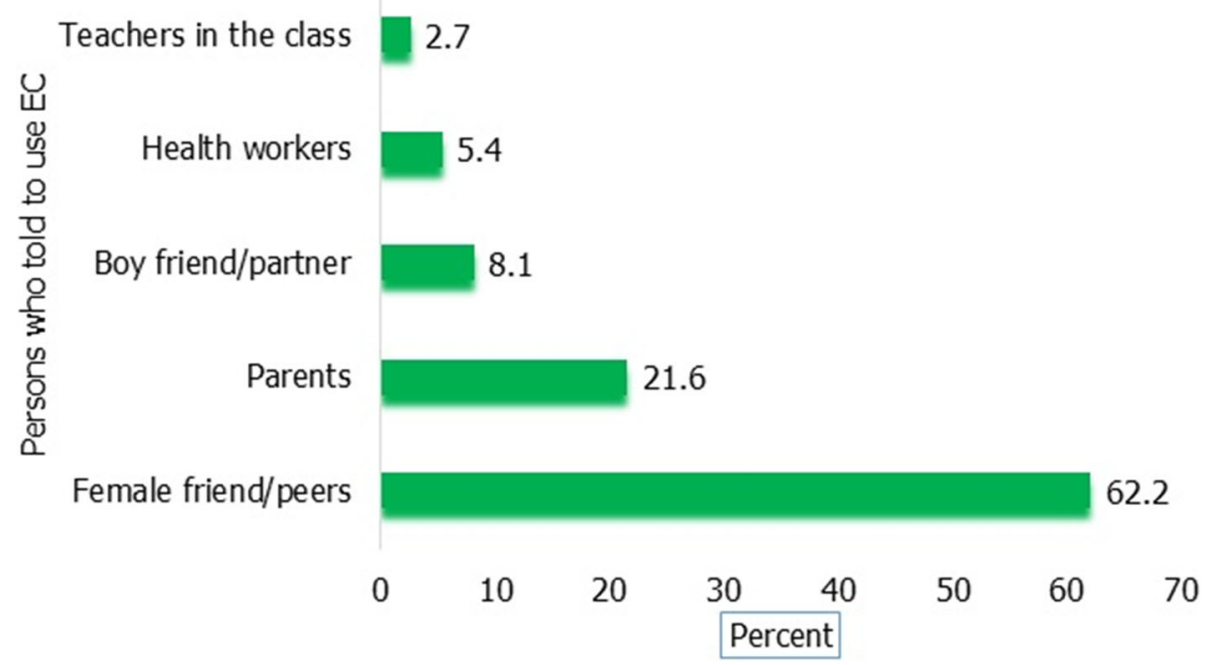

Fig. 2 Number of students who got advice to use EC after unprotected sex, Debre Tabor Town, Northwest Ethiopia June 2017 ( $n=37)$

Table 6 Bivariate and multivariate analysis on emergency contraceptive utilization among female college students in Debre Tabor Town northwest Ethiopia, October 2017 ( $n=263$ )

\begin{tabular}{|c|c|c|c|c|}
\hline \multirow[t]{2}{*}{ Variables } & \multicolumn{2}{|l|}{ EC used } & \multirow{2}{*}{$\begin{array}{l}\text { Crude OR } \\
(95 \% \mathrm{Cl})\end{array}$} & \multirow{2}{*}{$\begin{array}{l}\text { Adjusted OR } \\
(95 \% \mathrm{Cl})\end{array}$} \\
\hline & No (\%) & Yes (\%) & & \\
\hline \multicolumn{5}{|l|}{ Age (in years) } \\
\hline $15-19$ & $91(48.2)$ & $21(28.41)$ & 1.00 & 1.00 \\
\hline $20-24$ & $90(47.6)$ & $45(60.8)$ & $2.2(1.19,3.93)$ & $2.3(1.21,4.49)^{*}$ \\
\hline$>=25$ & $8(4.2)$ & $8(10.8)$ & $4.3(1.46,12.87)$ & $1.9(0.52,7.32)$ \\
\hline \multicolumn{5}{|l|}{ Marital Status } \\
\hline Never married & 169(89.4) & $49(66.2)$ & 1.00 & 1.00 \\
\hline Married & $16(8.5)$ & 19(25.3) & $4.1(1.96,8.56)$ & $2.8(1.22,6.21)^{*}$ \\
\hline Divorced & $4(2.1)$ & $6(8.1)$ & $5.2(1.40,19.07)$ & $4.9(1.12,21.08)^{*}$ \\
\hline \multicolumn{5}{|l|}{ Extra Job } \\
\hline Yes & $11(5.8)$ & $12(16.2)$ & $3.1(1.32,3.46)$ & $2.5(0.98,6.62)$ \\
\hline No & 178(94.2) & $62(83.8)$ & 1.00 & 1.00 \\
\hline \multicolumn{5}{|l|}{ Ever Pregnant } \\
\hline Yes & $6(3.2)$ & 14(18.9) & $7.1(2.62,19.34)$ & $3.7(0.50,27.99)$ \\
\hline No & 183(96.8) & $60(81.1)$ & 1.00 & \\
\hline \multicolumn{5}{|l|}{ Unintended pregnancy } \\
\hline Yes & $4(2.1)$ & $11(14.9)$ & $8.1(2.48,26.27)$ & $1.7(0.16,17.17)$ \\
\hline No & 185(97.9) & 63(81.1) & 1.00 & 01.0 \\
\hline \multicolumn{5}{|l|}{ Field of Study } \\
\hline Non-Health science & $91(48.1)$ & 25(33.8) & 1.00 & 1.00 \\
\hline Health science & $98(51.9)$ & $49(66.2)$ & $1.8(1.04,3.19)$ & $1.3(0.69,2.49)$ \\
\hline \multicolumn{5}{|l|}{ Knowledge } \\
\hline Good knowledge & $79(41.8)$ & $47(63.5)$ & $2.4(1.39,4.22)$ & $2.3(1.20,4.25)^{*}$ \\
\hline Poor knowledge & $110(58.2)$ & $27(36.5)$ & 1.00 & \\
\hline
\end{tabular}




\section{Conclusion}

The study finding pointed out that the proportion of emergency contraceptive utilization among female college students was low. Knowledge of students on EC, age at present, and marital status were found to be major determinants. Educating adolescents about emergency contraceptives to give attention to available methods, correct time of use, and promoting emergency contraceptives using formal and informal education like health education sessions gender club sensitization and peer education about sexual health and contraception so as to increase knowledge on EC and to enhance utilization and to make emergency contraceptive methods readily accessible.

\section{Abbreviations \\ EC: Emergency Contraceptive; HIV/AIDS: Human Immune Deficiency Virus/ Acquired Immune Deficiency Syndrome; IUCD: Intra-Uterine Contraceptive device N.B: $1.00=$ reference, ${ }^{*}=$ significantly associated factor Hosmier and Lemesho Goodness of fit test=0.591; STI: Sexually Transmitted Infection}

\section{Acknowledgments}

We sincerely acknowledge the Amhara Public Health Institute for giving permission letters to conduct this research. Our next appreciation goes to study participants, coordinators, data collection facilitators, and the staffs of the respective colleges.

\section{Authors' contributions}

Tadesse Wuletaw (TW) designed the study, participated in the data quality control, analyzed the data, and drafted the paper, Araya Mesfin (AM) and Getnet Mihretie (GM) assisted with the design, approved the proposal, and revised drafts of the paper. The authors read and approved the manuscript.

\section{Funding}

Self-funding.

\section{Availability of data and materials}

The original data are available at hand and maybe delivered upon request via the corresponding author.

\section{Ethics approval and consent to participate}

Ethical clearance was obtained from the Amhara Public Health Institute. The study participants were also informed about the objectives of the study, privacy, and data protection and gave informed consent before being enrolled in the study.

\section{Consent for publication}

Not applicable.

\section{Competing interests}

The authors declare that we have no competing interests.

\section{Author details}

'Department of Nursing, Debre Tabor Health Science College, Debra Tabor, Ethiopia. ${ }^{2}$ Department of Health Informatics, Institute of Public Health, University of Gondar, Gondar, Ethiopia. ${ }^{3}$ Department of Nursing, Debre Tabor University, Debra Tabor, Ethiopia.

Received: 2 November 2019 Accepted: 13 November 2020

Published online: 20 November 2020

\section{References}

1. Health WHOR. Family planning: a global handbook for providers: evidencebased guidance developed through worldwide collaboration. World Health Organization \& Johns Hopkins Bloomberg School of Public Health: Johns Hopkins Ccp-Info; 2007.

2. Glasier A, Gülmezoglu AM, Schmid GP, Moreno CG, Van Look PF. Sexual and reproductive health: a matter of life and death. Lancet. 2006;368(9547):1595-607.
3. Mosher WD, Jones J. Use of contraception in the United States: 1982-2008. Vital Health Stat Ser 23, Data Nat Survey Family Growth. 2010;(29):1-44.

4. Palermo T, Bleck J, Westley E. Knowledge and use of emergency contraception: a multicountry analysis. Int Perspect Sex Reprod Health. 2014;40(2):79-86.

5. Sabo L, Schrager S. Emergency contraception in Wisconsin: a review. WMJMADISON-. 2006;105(5):40

6. Cleland J, Bernstein S, Ezeh A, Faundes A, Glasier A, Innis J. Family planning: the unfinished agenda. Lancet. 2006;368(9549):1810-27.

7. Hoque ME, Ghuman S. Knowledge, practices, and attitudes of emergency contraception among female university students in KwaZulu-Natal, South Africa; 2012

8. Ojule JD, Oriji VK, Georgewill KN. Awareness and practice of emergency contraception among students of University of Port Harcourt, south-South Nigeria. Nigerian Health J. 2008;8(1-2):6-9.

9. Worku A. Knowledge, attitude and practice of emergency contraceptives among female college students in Arba Minch town, southern Ethiopia. Ethiop J Health Dev. 2011;25(3):176-83.

10. Amalba A, Mogre V, Appiah MN, Mumuni WA. Awareness, use and associated factors of emergency contraceptive pills among women of reproductive age (15-49 years) in tamale, Ghana. BMC Womens Health. 2014;14(1):114.

11. Wang H, Long L, Cai H, Wu Y, Xu J, Shu C, et al. Contraception and unintended pregnancy among unmarried Female University students: a cross-sectional study from China. PLoS One. 2015;10(6):e0130212.

12. Commission FDRoEPC. Summary and statistical report of the 2007 population and housing census. Addis Ababa: Federal Democratic republic of Ethiopia Population Census Commission; 2008.

13. Shiferaw BZ, Gashaw BT, Tesso FY. Factors associated with utilization of emergency contraception among female students in Mizan-Tepi University, south West Ethiopia. BMC Res Notes. 2015;8(1):817.

14. Tilahun D, Assefa T, Belachew T. Predictors of emergency contraceptive use among regular female students at Adama University, Central Ethiopia. Pan Afr Med J. 2010;7(1)

15. Seife M. Assessment of level of awareness and utilization of emergency contraception, among college female students in Oromia regional state, Arsi zone, Asella town south-East Ethiopia: aau; 2007.

16. Tilahun D, Assefa T, Belachew T. Knowledge, attitude and practice of emergency contraceptives among Adama University female students, Ethiopia. Ethiop J Health Sci. 2010;20(3).

17. Tolossa E, Meshesha B, Abajobir AA. Assessment of level of knowledge and utilization of emergency contraception among female students of Hawassa University, South Ethiopia. Adv Reprod Sci. 2013;1(03):51.

18. Tajure N. Knowledge, attitude and practice of emergency contraception among graduating female students of Jimma University, Southwest Ethiopia. Ethiop J Health Sci. 2010;20(2).

19. Adinma ED, Adinma JIB-D, Eke NO, Iwuoha C, Akiode A, Oji E. Awareness and use of contraception by women seeking termination of pregnancy in south eastern Nigeria. Asian Pacific J Trop Dis. 2011;1(1):71-5.

20. Worku A. Knowledge, attitude and practice of emergency contraceptives among female college students in Arba Minch town, southern Ethiopia. Ethiop J Health Dev. 2012;25(3):176-83.

\section{Publisher's Note}

Springer Nature remains neutral with regard to jurisdictional claims in published maps and institutional affiliations.
Ready to submit your research? Choose BMC and benefit from:
- fast, convenient online submission
- thorough peer review by experienced researchers in your field
- rapid publication on acceptance
- support for research data, including large and complex data types
- gold Open Access which fosters wider collaboration and increased citations
- maximum visibility for your research: over $100 \mathrm{M}$ website views per year
At $\mathrm{BMC}$, research is always in progress.
Learn more biomedcentral.com/submission 